\title{
Four new species of Rhinocricus (Diplopoda: Spirobolida: Rhinocricidae) from Brazil
}

\author{
Patrícia E. S. Rodrigues ${ }^{1}$ (D), Everton N. L. Rodrigues ${ }^{1}$ (D) \& Ricardo Ott ${ }^{2}$
}

\begin{abstract}
1. Laboratório de Diversidade e Sistemática de Arachnida, Programa de Pós-graduação em Biologia, Universidade do Vale do Rio dos Sinos - UNISINOS, Av. Unisinos, 950, 93022-000 São Leopoldo, RS, Brazil. (patiesilva@yahoo.com.br)

2. Museu de Ciências Naturais, Fundação Zoobotânica do Rio Grande do Sul. Rua Dr. Salvador França, 1427, $90690-000$ Porto Alegre, RS, Brazil.
\end{abstract}

Received 7 March 2018

Accepted 01 August 2018

Published 17 September 2018

DOI 10.1590/1678-4766e2018031

\begin{abstract}
The genus Rhinocricus Karsch, 1881 currently includes more than 60 species described and registered from Brazil. In this paper, four new species from southern and southeastern Brazil are described and illustrated: Rhinocricus sooretama sp. nov., Rhinocricus bifurcatus sp. nov., Rhinocricus montenegrinus sp. nov., and Rhinocricus fortaleza sp. nov. All new species are based on both sexes.
\end{abstract}

KEYWORDS. Neotropical, taxonomy, systematics.

RESUMO. Quatro novas espécies de Rhinocricus (Diplopoda: Spirobolida: Rhinocricidae) do Brasil. O gênero Rhinocricus Karsch, 1881 inclui atualmente mais de 60 espécies descritas e registradas para o Brasil. Neste artigo, são descritas e ilustradas quatro novas espécies do Sul e do Sudeste do Brasil: Rhinocricus sooretama sp. nov., Rhinocricus bifurcatus sp. nov., Rhinocricus montenegrinus sp. nov. e Rhinocricus fortaleza sp. nov. Todas as novas espécies são baseadas em ambos os sexos.

PALAVRAS-CHAVE. Neotropical, taxonomia, sistemática.

More than 500 species of the millipede family Rhinocricidae Brölemann, 1913 are currently grouped into 30 genera (MAREK et al., 2003; ENGHOFF et al., 2015). Members of this family are distributed in South America, Central America, North America, the West Indies, Australia, Oceania, Southeast Asia and Taiwan (Enghoff et al., 2015). Most of the species from Brazil was described in Rhinocricus Karsch, 1881 by SchUBART $(1944,1951,1962)$. This genus is the largest of the family, with 207 described species distributed mainly in South America, Central America and the West Indies (ENGHOFF et al., 2015). The genus is characterized by the scobinae (paired paramedian depressions in the anterior portion of prozonites), in having the posterior gonopod bifurcate and by showing numerous sensory cones on the tip of the antennae. In this paper we describe and illustrate four new species of Rhinocricus from southern and southeastern Brazil.

\section{MATERIAL AND METHODS}

The material examined is deposited in the following institutions (curator in parentheses): MCN, Museu de Ciências Naturais, Fundação Zoobotânica do Rio Grande do Sul, Porto Alegre, RS, Brazil (R. Ott) and MZSP, Museu de Zoologia, Universidade de São Paulo, São Paulo, SP, Brazil (R. Pinto-da-Rocha). The specimens are preserved in $80 \%$ ethanol. For the examination of somatic characters, measurements and illustrations of the gonopods, we used a stereomicroscope with a measuring eyepiece and a coupled drawing attachment. Photographs were taken with a Motic SMZ168 stereo microscope with an attached camera, coupled with "Motic Moticam Pro 2500 digital imaging system" software. To edit images we used CorelDRAW Graphics Suite X5. The terminology of the gonopods follows SCHUbart (1951), HofFMAN (1980) and Bond \& MAREK (2003). All measurements are in millimeters. The coloration of all species refers to material preserved in alcohol. All type specimens are deposited in the Museu de Ciências Naturais da Fundação Zoobotânica (MCN), Porto Alegre, state of Rio Grande do Sul, Brazil.

\section{TAXONOMY}

\section{Rhinocricus sooretama sp. nov.}

(Figs 1-3, 7, 8)

urn:Isid:zoobank.org:act:FFFED2B9-33AC-43E9-B116B410DD7FB81F 
Type material. Male holotype from Sooretama, 19¹1'49”S, 4005'52”'W, Espírito Santo, Brazil, 24.II.2011, A. Fabian leg. (MCN 1178). Paratypes: nine ${ }^{\lambda}$ and eight + , same data as the holotype (MCN 1179).

Etymology. The specific name is a noun in apposition, taken from the type locality.

Diagnosis. Rhinocricus sooretama sp. nov. resembles $R$. klossae Schubart, 1958 (see Schubart, 1958b:6, figs 5-7) and R. punctatofasciatus Schubart, 1958 (see SCHUBART, 1958a:229, figs 23-26) by the shape of the posterior gonopod with the inner edge of the external branch showing a needle-shaped terminal process (Fig. 3 ), but differs from these species by the sternite of the anterior gonopod carrying a rounded projection at the tip (Figs 1, 2).

Description. Male holotype (Figs 7, 8) with 64 rings. Length 76 . Width 6 . General coloration yellowish brown. Clypeus with spaced 2-2 supra-labral setae. Collum with yellowish margins and ventro-lateral rounded borders. Prozonites yellowish brown; metazonites brown with posterior margins yellowish. Ocelli black, arranged in six rows. Ozopores beginning at the sixth ring. Scobinae semicircular beginning at sixth ring. Third and fourth pairs of legs with elongated coxae. Telson brown (Fig. 8) with epiproct elongated surpassing the paraprocts. Hypoproct semicircular.
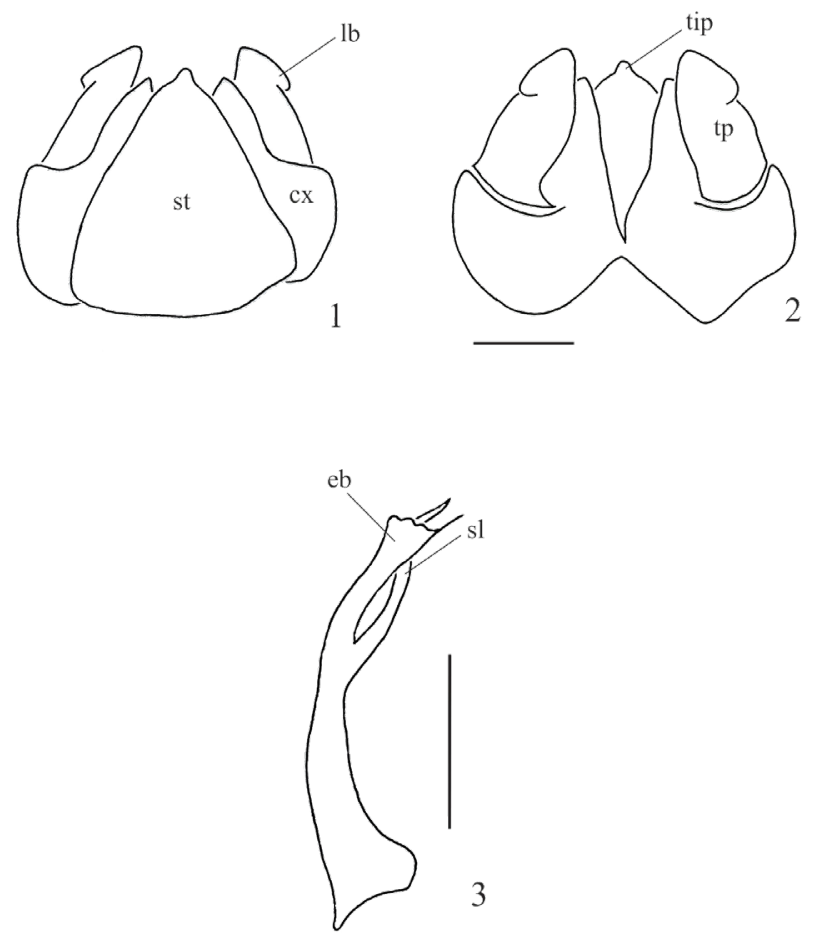

Figs 1-3. Rhinocricus sooretama sp. nov. Figs 1, 2, anterior gonopod: 1, anterior view; 2, posterior view. Fig. 3, posterior gonopod (cx, coxite; st, sternite; sl, solenomere; tp, telopodite; eb, external branch; lb, lobe of telopodite; tip, apice of coxite). Scale bar $=1.0 \mathrm{~mm}$.
Anterior gonopod (Figs 1, 2) with subtriangular sternite longer than wide, tip pointed. Sternite shorter than telopodite, longer than coxite. Coxite with internal obtuse lobe shorter than telopodite. Telopodite with scarcely evident lobe (Fig. 2).

Posterior gonopod (Fig. 3). Solenomere distally pointed, longer than external branch. External branch lamellate, internally with needle shaped process and externally rounded.

Female paratype with 59 rings. Length 81 . Width 7 . General coloration yellowish brown.

Distribution. Known only from the type locality, Sooretama, state of Espírito Santo, Southeast Brazil.

\section{Rhinocricus bifurcatus sp. nov.}

(Figs 4-6, 9, 10)

urn:lsid:zoobank.org:act:CE570255-AF01-4AE4-BCCC-0CB603452752

Type material. Male holotype from Foz do Iguaçu, 2532’50.1”S, 5434’44.0”W, Paraná, Brazil, 09-11.

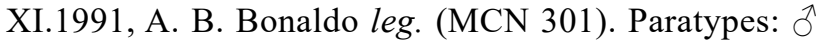
and $\circ$ from Tenente Portela, 27 $22^{\prime} 16^{\prime}$ 'S, 53 $3^{\circ} 45^{\prime} 30^{\prime \prime} \mathrm{W}$, Rio Grande do Sul, Brazil, 29.XI.1978, H. Bischoff leg. (MCN 137).

Etymology. The specific epithet is a Latin adjective and refers to the bifurcate shape of the external branch of the posterior gonopod.

Diagnosis. Rhinocricus bifurcatus sp. nov. resembles R. moestus Brölemann, 1901 (see BRöLEMANN, 1901:200, figs 255-261) and $R$. divaricatus Schubart, 1951 (see SCHUBART, 1951:254, figs 21, 22) by having the external branch of the posterior gonopod bifurcate (Fig. 6) and by the shape of the anterior gonopod (Fig. 4), but differs by the subtriangular sternite and by the coxite shorter than the telepodite (Fig. 4).

Description. Male holotype (Figs 9, 10) with 56 rings. Length 65. Width 6. General coloration brown. Clypeus with spaced 2-2 supra-labral setae. Antennae flattened, the three last antennomeres with some setae. Prozonites gray; metazonites with yellowish brown posterior margins. Ocelli black, arranged in seven rows.

Ozopores beginning at the sixth ring. Scobinae semicircular beginning at sixth ring. Third and fourth pairs of legs with elongated coxae. Telson (Fig. 10) with epiproct elongated surpassing the paraprocts. Hypoproct semicircular.

Anterior gonopod (Figs 4, 5) with a subtriangular sternite longer than wide, distally rounded. Sternite shorter than coxite and telopodite. Coxite wide with an internal acute lobe, which is shorter than the telopodite and has an evident distal lobe.

Posterior gonopod (Fig. 6). Solenomere distally pointed, longer than external branch. External branch slender, distally bifurcated, internally pointed and externally rounded. 

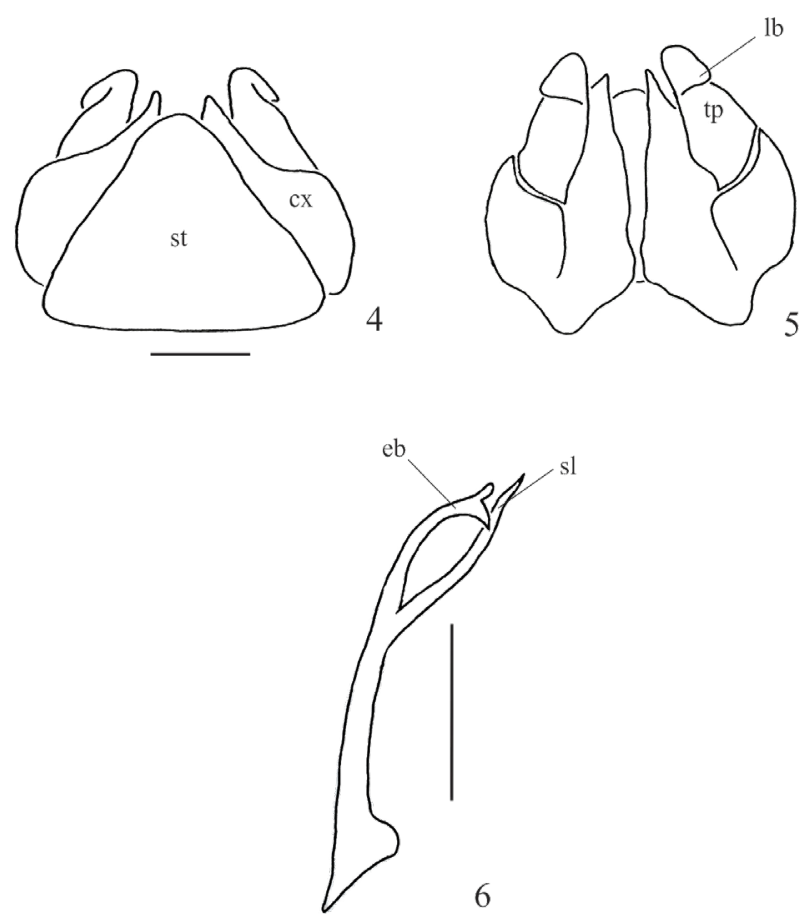

Figs 4-6. Rhinocricus bifurcatus sp. nov. Figs 4,5, anterior gonopod: 4 , anterior view; 5, posterior view. Fig. 6, posterior gonopod (cx, coxite; st, sternite; slm, solenomere; tp, telopodite; eb, external branch; lb, lobe of telopodite). Scale bar $=1.0 \mathrm{~mm}$.

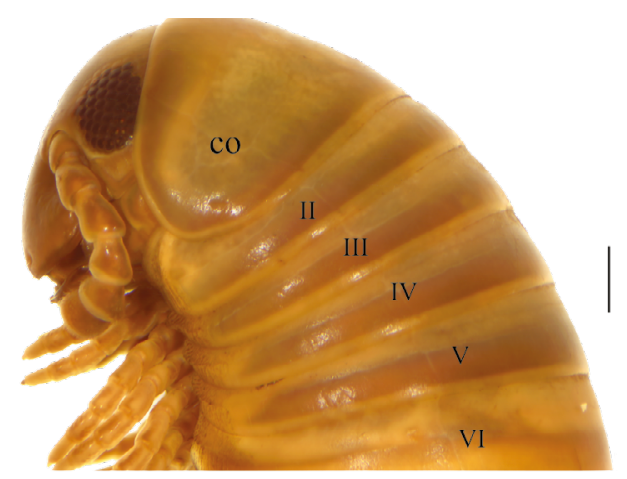

7
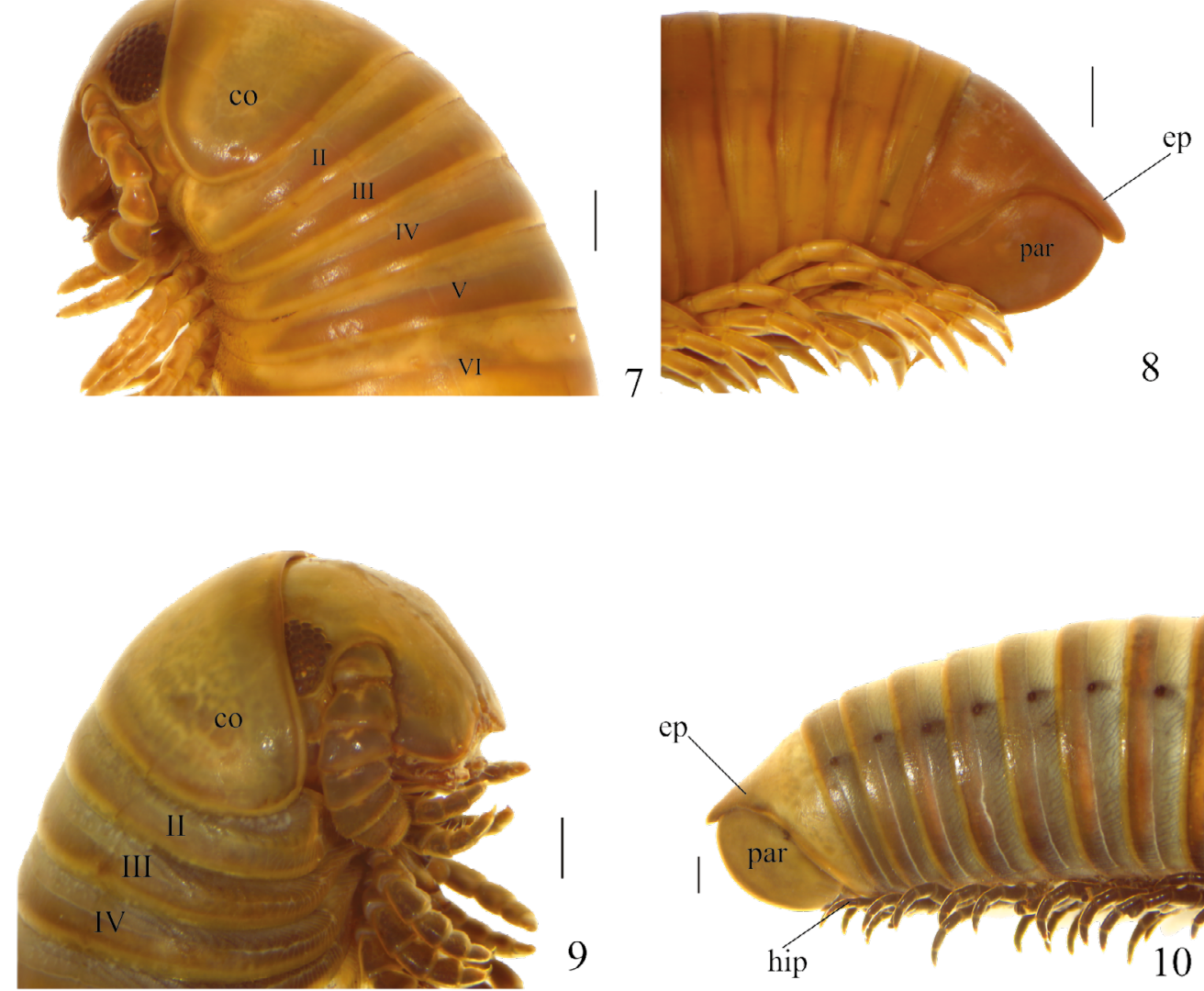

Female paratype with 57 rings. Length 78 . Width 7. General coloration light brown.

Distribution. Known from southern Brazil, Foz do Iguaçu, state of Paraná and Tenente Portela, state of Rio Grande do Sul.

\section{Rhinocricus montenegrinus sp. nov.}

(Figs 11, 12; 16, 17)

urn:lsid:zoobank.org:act:F07E52B2-EF97-4235-8A9B-497C74E57C8F

Type material. Male holotype from Montenegro, 29॰41'19”S, 51 27’40”W, Rio Grande do Sul, Brazil, 11.VIII.1977, V. Pitoni leg. (MCN 0098). Paratypes: two $\delta$ and three $q$, same data as the holotype (MCN 0099).

Etymology. The specific name is a Latin adjective derived from the type locality.

Diagnosis. Rhinocricus montenegrinus sp. nov. resembles $R$. jandirae Schubart, 1944 (see Schubart, 1944:387, figs 54,55 ) by the shape of the external branch of the posterior gonopod which is distally quadrate, but differs by the sternite of the anterior gonopod being longer than wide, distally projecting and rounded, and by a rounded distal lobe of the coxite (Fig. 11).

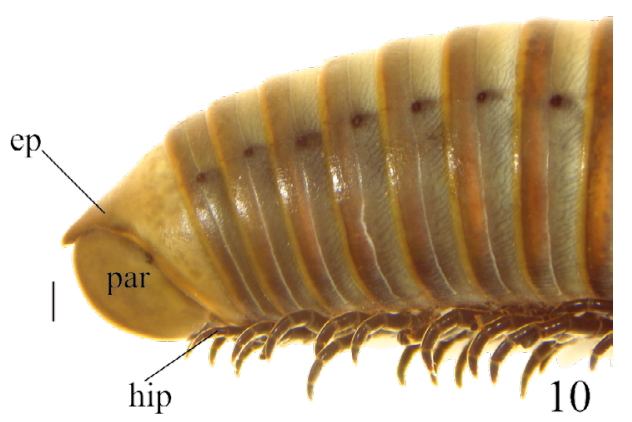

Figs 7-10. Rhinocricus sooretama sp. nov. Figs 7, 8, holotype ${ }^{7}$, lateral view: 7, anterior rings; 8, posterior rings. Figs 9, 10, Rhinocricus bifurcatus holotype 3 , lateral view: 9, anterior rings; 10, posterior rings (co, collum; II, second ring; III, third ring; IV, four ring; V, five ring; IV, six ring; par, paraproct; ep, epiproct; hyp, hypoproct). Scale bar $=2.0 \mathrm{~mm}$. 
Description. Male holotype (Figs 16, 17) with 52 rings. Length 58. Width 5 . General coloration ligtht brown. Clypeus with spaced 2-2 supra-labral setae. Metazonites with posterior margins yellowish-brown. Ocelli black, arranged in seven rows. Ozopores beginning at the sixth ring. Scobinae semicircular beginning at sixth ring. Third and fourth pairs of legs with elongated coxae. Telson (Fig. 17) with epiproct elongated surpassing the paraprocts. Hypoproct semicircular.

Anterior gonopod (Fig. 11) with subtriangular sternite longer than wide, distally projecting and rounded. Sternite longer than coxite but shorter than telopodite. Coxite with evident lobe, shorter than telopodite and sternite. Telopodite with evident distal lobe.

Posterior gonopod (Fig. 12). Solenomere distally pointed, shorter than external branch. External branch lamellate, distally quadrate.

Female paratype with 53 rings. Length 56 . Width 5 . General coloration light brown.

Distribution. Known only from the type locality, Montenegro, state of Rio Grande do Sul, South Brazil.

\section{Rhinocricus fortaleza sp. nov.}

(Figs. 13-15, 18-20)

urn:1sid:zoobank.org:act:4E884950-07D4-4E67-9110-ADEBC10E595F

Type material. Male holotype from Cambará do Sul, Parque Nacional de Aparados da Serra, canion Fortaleza, 29¹1'30'S, 505'51'W, Rio Grande do Sul, Brazil, 09.I.1976, A. A. Lise leg. (MCN 0007). Paratypes: three $\widehat{\varnothing}$ and four $q$ same data as the holotype (MCN 0008).

Etymology. The specific name is a noun in apposition, taken from the type locality.

Diagnosis. Rhinocricus fortaleza sp. nov. resembles $R$. avanhandavae Schubart, 1951 (see SCHUBART, 1951:245, figs $11,12)$ in the shape of the sternite of the anterior gonopod, which has a pointed tip and is longer than the coxite and telopodite (Fig. 13), but differs in the shape of the posterior gonopod, with the solenomere being distally pointed, shorter than the external branch (Fig. 15).

Description. Holotype $\widehat{\jmath}$ (Figs 18-20) with 61 rings. Length 62. Width 7. General coloration yellowish brown. Clypeus with spaced 2-2 supra-labral setae. Antennae with three last antennomeres with some setae. Prozonites and metazonites yellow, but posterior margins of metazonites brown. Ocelli black, arranged in seven rows. Ozopores beginning at the sixth ring. Scobinae semicircular beginning at sixth ring. Legs yellow, with elongated coxae at third and fourth pairs of legs. Telson (Fig. 20) yellow with epiproct elongated, surpassing the paraprocts. Hypoproct semicircular.

Anterior gonopod (Figs 13, 14) with subtriangular sternite longer than wide, distally rounded. Sternite longer
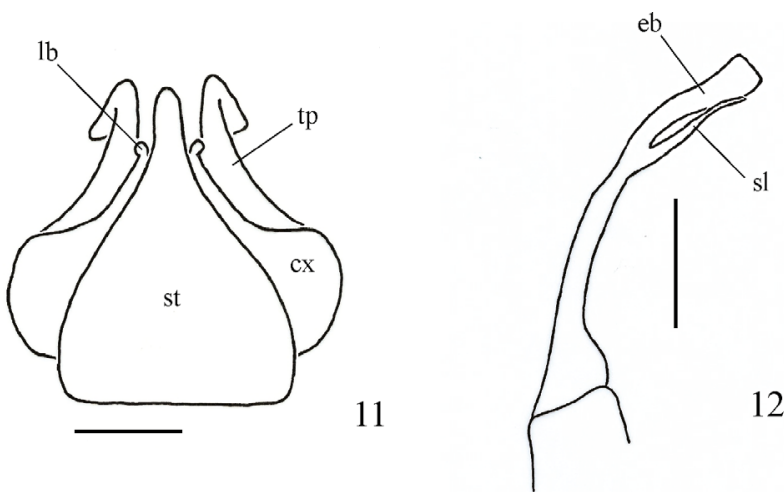

Figs 11-12. Rhinocricus montenegrinus sp. nov. Figs 11, 12, anterior gonopod: 11, anterior view; 12, posterior gonopod (cx, coxite; st, sternite; $\mathrm{sl}$, solenomere; tp, telopodite; eb, external branch; lb, lobe of coxite). Scale bar $=1.0 \mathrm{~mm}$.
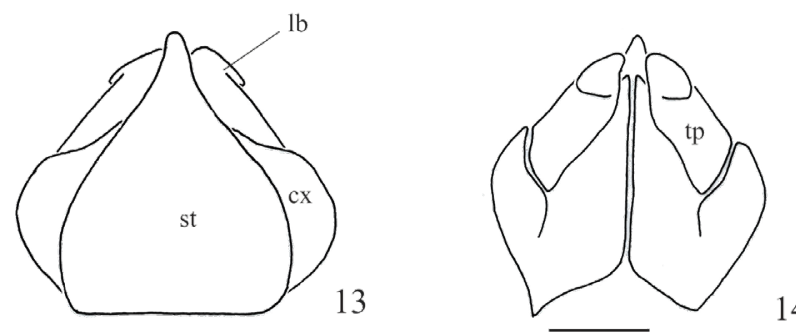

14

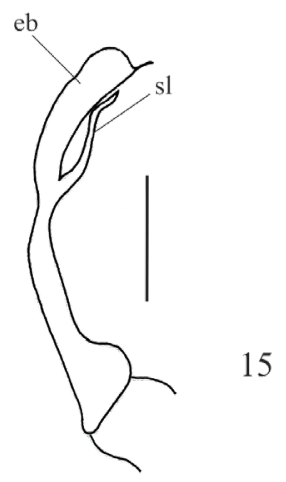

Figs 13-15. Rhinocricus fortaleza sp. nov. Figs 13, 14, anterior gonopod: 13 , anterior view; 14, posterior view. Fig. 15, posterior gonopod (cx, coxite; st, sternite; sl, solenomere; tp, telopodite; eb, external branch; lb, lobe of telopodite). Scale bar $=1.0 \mathrm{~mm}$.

than coxite and telopodite. Coxite shorter than telopodite.

Posterior gonopod (Fig. 15). Solenomere distally pointed, shorter than external branch. External branch lamellate, externally rounded and internally with a sharp and projecting distal end.

Female paratype with 62 rings. Length 64 . Width 7. General coloration yellow.

Distribution. Known only from the type locality, Cambará do Sul, state of Rio Grande do Sul, South Brazil. 

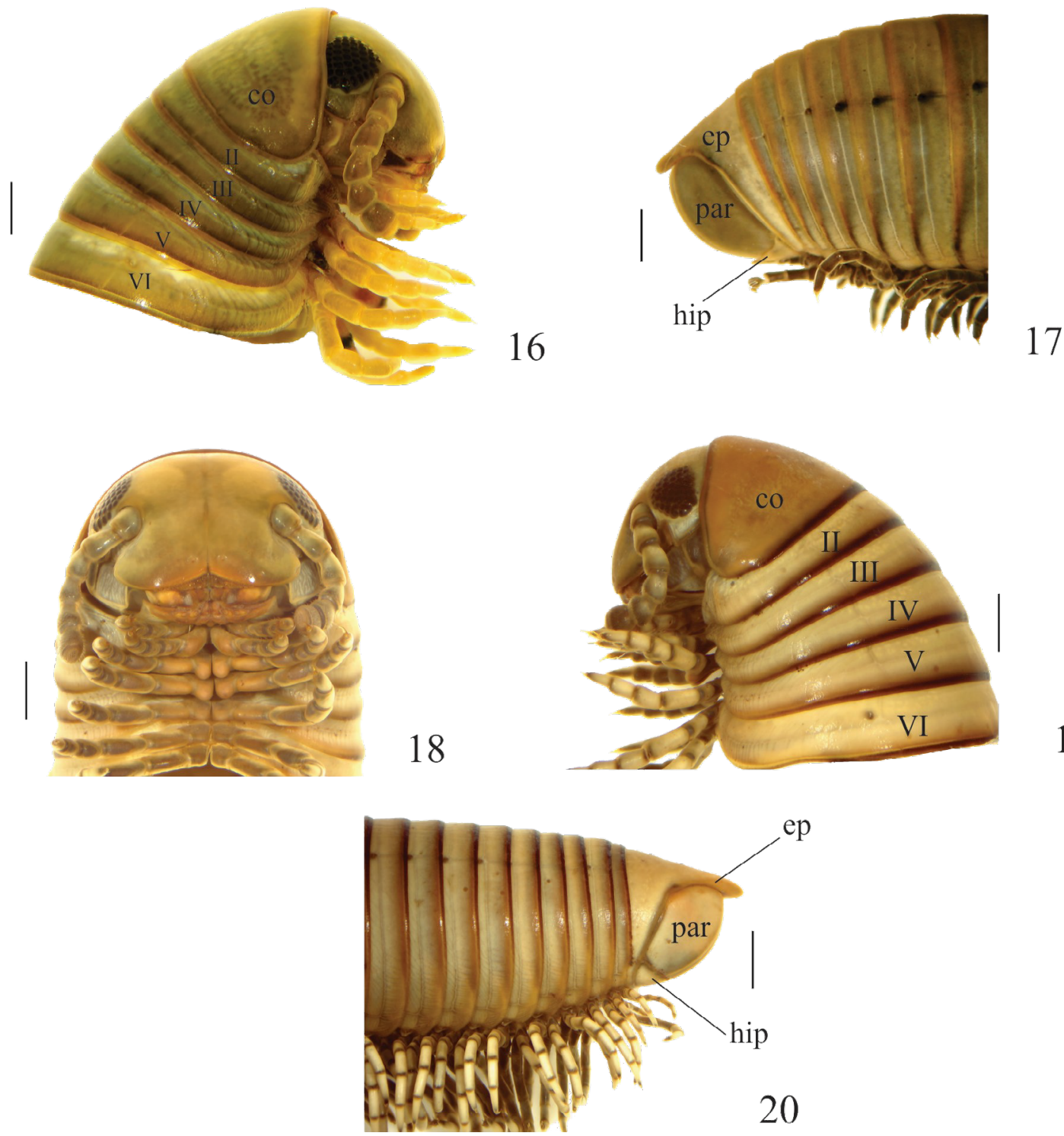

Figs 16-20. Rhinocricus montenegrinus sp. nov. Figs 16,17, holotype đ̊, lateral view: 16, anterior rings; 17, posterior rings. Figs 18-20, Rhinocricus fortaleza sp. nov., holotype $\delta^{\top}: 18$, ventral view; 19, anterior rings; 20, posterior rings (co, collum; II, second ring; III, third ring; IV, four ring; V, five ring; IV, six ring; par, paraproct; ep, epiproct; hyp, hypoproct). Scale bar $=2.0 \mathrm{~mm}$.

Acknowledgements. This study was part of dissertation of the first author and developed at Programa de Pós-graduação em Biologia Animal, UFRGS and supported by CAPES (P.E.S. Rodrigues). We thank Ricardo Pinto-da-Rocha (MZUSP) for providing type material for examination.

\section{REFERENCES}

Bond, J. E. \& Marek, P. E. 2003. Rhinocricidae Systematics I: The taxonomic placement of the species of Zipyge Chamberlin, 1925 and Oxypygides Chamberlin, 1922 (Diplopoda: Spirobolida: Rhinocricidae: Oxypyginae). Zootaxa 292:1-8.

Brölemann, H. W. 1901. Myriapodes du Musee de Sao Paolo. Revista Museu Paulista 5:35-237.

Enghoff, E.; Golovatch, S. I.; Short, M.; Stoev, P. \& Wesener, T. 2015. Diplopoda- Taxonomic overview. In: Minelli, A. ed. Treatise on Zoology - Anatomy, Taxonomy, Biology. The Myriapoda, vol. 2. Leiden, Boston, Brill, p. 363-455.
Hoffman, R. L. 1980. Studies on spiroboloid millipeds. XI. On the status of Spirobolus nattereri Humbert \& DeSaussure, 1870, and some species traditionally associated with it (Rhinocricidae). Papéis Avulsos de Zoologia 33:177-181.

MaReK, P. E.; Bond, J. E. \& Sierwald, P. 2003. Rhinocricidae Systematics II: The species catalog of the Rhinocricidae (Diplopoda: Spirobolida) with synonymies. Zootaxa 308:1-108.

Schubart, O. 1944. Os Diplopodos do Pirassununga. Acta Zoologica Lilloana 2:321-440.

SCHUBART, O. 1951. Contribution for the fauna of the state of São Paulo. II. Rhinocricidae (Opisthospermophora, Diplopoda). Anais da Academia Brasileira de Ciências 23:221-275.

Schubart, O. 1958a. Sôbre alguns Diplopoda de Mato Grosso e Goiás, Brasil e a Família Spirostreptidae. Arquivos do Museu Nacional, Rio de Janeiro 46:203-252.

SchUBART, O. 1958b. Sôbre alguns Diplopoda do Estado do Pará (Brasil), colecionados por Lauro Travassos, Gertrud Rita Kloss e Fernando D. A. Pires. Boletim do Museu Paraense Emílio Goeldi 16:1-30.

Schubart, O. 1962. Novas espécies brasileiras da Família Rhinocricidae (Diplopoda, Opisthospermophora). Anais da Academia Brasileira de Ciências 34:69-87. 